TINJAUAN TEORITIS

\title{
PEMBANGUNAN WILAYAH PESISIR DAN LAUTAN DALAM PERSPEKTIF NEGARA KEPULAUAN REPUBLIK INDONESIA
} Regional Development in Coastal and Ocean in Archipelago Perspective of The Republic of Indonesia

\author{
Ridwan Lasabuda ${ }^{1}$
}

\begin{abstract}
Indonesian as an archipelagic state has been recognized internationally (UNCLOS 1982), later ratified by Act 17 of 1985. Under UNCLOS 1982, the total maritime area of Indonesia is 5.9 million $\mathrm{km}^{2}$, consisting of 3.2 million $\mathrm{km}^{2}$ of territorial waters and $2.7 \mathrm{~km}^{2}$ of Economic Exclusive Zone (Zone Ekonomi Ekslusif), not including the continental shelf. This makes Indonesia as the largest archipelagic state in the world. However, the development of marine and fisheries for this is still far from expectations, while large potential of natural resources and environmental services are relatively unexploited in coastal areas, small islands and ocean in Indonesian archipelago.
\end{abstract}

Keywords : coastal and ocean, development, Indonesian, archipelago

\section{ABSTRAK}

Sebagai negara kepulauan, Indonesia telah diakui dunia secara internasional (UNCLOS 1982) yang kemudian diratifikasi oleh Indonesia dengan UndangUndang No.17 Tahun 1985. Berdasarkan UNCLOS 1982, total luas wilayah laut Indonesia seluas 5,9 juta $\mathrm{km}^{2}$, terdiri atas 3,2 juta $\mathrm{km}^{2}$ perairan teritorial dan 2,7 $\mathrm{km}^{2}$ perairan Zona Ekonomi Eksklusif, luas tersebut belum termasuk landas kontinen. Hal ini menjadikan Indonesia sebagai negara kepulauan terbesar di dunia. Namun demikian, pembangunan bidang kelautan dan perikanan hingga saat ini masih jauh dari harapan. Padahal wilayah pesisir dan pulau-pulau kecil dan lautan kepulauan Indonesia disimpan potensi sumber daya alam dan jasa lingkungan yang sangat besar dan belum dimanfaatkan secara optimal.

Kata kunci : pesisir dan laut, pembangunan, Indonesia, kepulauan

\footnotetext{
${ }^{1}$ Laboratorium Pengelolaan Wilayah Pesisir Terpadu, FPIK UNSRAT
} 


\section{PENDAHULUAN}

Secara geografis Indonesia membentang dari $6^{\circ}$ LU sampai $11^{\circ}$ LS dan $92^{\circ}$ sampai $142^{\circ} \mathrm{BT}$, terdiri dari pulaupulau besar dan kecil yang jumlahnya kurang lebih 17.504 pulau. Tiga perempat wilayahnya adalah laut $(5,9$ juta $\mathrm{km}^{2}$ ), dengan panjang garis pantai $95.161 \mathrm{~km}$, terpanjang kedua setelah Kanada.

Melalui Deklarasi Djuanda, 13 Desember 1957, Indonesia menyatakan kepada dunia bahwa laut Indonesia (laut sekitar, di antara, dan di dalam kepulauan Indonesia) menjadi satu kesatuan wilayah NKRI. Dan Indonesia sebagai negara kepulauan, telah diakui dunia internasional melalui konvensi hukum laut PBB ke tiga, United Nation Convention on the Law of the Sea 1982 (UNCLOS 1982), kemudian diratifikasi oleh Indonesia dengan UndangUndang No.17 Tahun 1985. Berdasarkan UNCLOS 1982, total luas wilayah laut Indonesia menjadi 5,9 juta $\mathrm{km}^{2}$, terdiri atas 3,2 juta $\mathrm{km}^{2}$ perairan teritorial dan $2,7 \mathrm{~km}^{2}$ perairan Zona Ekonomi Eksklusif, luas perairan ini belum termasuk landas kontinen (continental shelf). Hal ini menjadikan Indonesia sebagai negara kepulauan terbesar di dunia (the biggest Archipelago in the World).

Pasal 25A UUD 1945 (hasil amandemen kedua UUD 1945), menyebutkan bahwa "NKRI adalah negara kepulauan yang berciri nusantara dengan wilayah yang batas-batas dan hak-haknya ditetapkan dengan Undang-undang". Ini semakin mengukuhkan eksistensi Indonesia sebagai negara maritim. Apalagi dengan lahirnya UU N0.27 Tahun 2007 tentang Pengelolaan Wilayah Pesisir dan Pulau-pulau Kecil, lebih jelas mengakui eksistensi sektor kelautan dan perikanan serta pengelolaan wilayah pesisir dan pulau-pulau kecil sebagai salah satu agenda pembangunan nasional. Namun faktanya, pembangunan bidang kelautan dan perikanan hingga saat belum dimanfaatkan secara optimal, padahal tersimpan potensi SDA dan jasa-jasa lingkungan yang sangat besar. Sehingga untuk menjadikan sektor kelautan dan perikanan sebagai arus utama pembangunan nasional dibutuhkan kebijakan pembangunan yang terpadu dan berbasiskan ekosistem.

\section{PEMBAHASAN}

\section{Potensi dan keunggulan sumber- daya pesisir dan lautan Indonesia}

\section{Potensi wilayah}

Posisi geografis kepulauan Indonesia sangat strategis karena merupakan pusat lalu lintas maritim antar benua. Indonesia juga memiliki kedaulatan terhadap laut wilayahnya meliputi; perairan pedalaman, perairan nusantara, dan laut teritorial (sepanjang 12 mil dari garis dasar). Disamping itu ada juga zona tambahan Indonesia, yang memiliki hak-hak berdaulat dan kewenangan tertentu. Selain itu, ada juga Zona Ekonomi Eksklusif Indonesia (ZEEI) sejauh 200 mil dari garis pangkal, dimana Indonesia mempunyai hak-hak berdaulat atas kekayaan alam (perikanan), kewenangan untuk memelihara lingkungan laut, mengatur dan mengizinkan penelitian ilmiah kelautan, pemberian ijin pembangunan pulaupulau buatan, instalasi dan bangunan2 lainnya.

\section{Potensi sumberdaya hayati Indonesia sebagai negara tropis,} kaya akan sumberdaya hayati, yang dinyatakan dengan tingkat keanekaragaman hayati yang tinggi. Dari 7000 spesies ikan di dunia, 2000 jenis diantaranya terdapat di Indonesia. Potensi lestari sumberdaya perikanan laut Indonesia kurang lebih 6,4 juta ton per tahun, terdiri dari : ikan pelagis besar $(1,16$ juta ton), pelagis kecil $(3,6$ juta ton), demersal (1,36 juta ton), udang penaeid (0,094 juta ton), lobster $(0,004$ juta ton), cumi-cumi $(0,028$ juta ton), dan ikan-ikan karang konsumsi $(0,14$ juta ton). Dari potensi tersebut jumlah tangkapan yang dibolehkan 
(JTB) sebanyak 5,12 juta ton per tahun, atau sekitar $80 \%$ dari potensi lestari. Potensi sumberdaya ikan ini tersebar di 9 (sembilan) wilayah Pengelolaan Perikanan Indonesia.

Potensi budidaya laut, terdiri dari potensi budidaya ikan (kakap, kerapu, gobia); udang, moluska (kerangkerangan, mutiara, teripang); dan rumput laut, potensi luasan budidayanya sebesar 2 juta ha $(20 \%$ dari total potensi lahan perairan pesisir dan laut berjarak $5 \mathrm{~km}$ dari garis pantai) dengan volume 46,73 juta ton per tahun. Sedangkan potensi budidaya payau (tambak) mencapai 913.000 ha. Untuk potensi bioteknologi kelautan masih besar peluangnya untuk dikembangkan, seperti industri bahan baku untuk makanan, industri bahan pakan alami, dan benih ikan dan udang.

Perairan Indo-Pasifik, yang sebagian besar terletak di perairan Indonesia merupakan pusat keanekaragaman terumbu karang dunia, dengan lebih dari 400 spesies. Juga berbagai jenis ganggang laut tersebar di berbagai wilayah pantai. Sumberdaya hayati laut kita, selain memiliki keanekaragaman hayati yang tinggi juga mempunyai luas habitat yang besar, yaitu : 2,4 juta ha kawasan hutan bakau dan 8,5 juta ha terumbu karang. Secara biologi, kawasan pesisir dan laut Indonesia juga mempunyai nilai global, karena perairan Indonesia merupakan tempat bertelur ikan-ikan yang bermigrasi (highly migratory species) seperti tuna, lumbalumba dan berbagai jenis ikan paus serta penyu.

Potensi kelautan dan perikanan di atas, guna mendorong pertumbuhan ekonomi diperkirakan mempunyai nilai potensi ekonomi masing-masing : perikanan tangkap US\$15,1 miliar per tahun; budidaya laut US\$ 46,7 miliar per tahun; budidaya tambak US\$10 miliar per tahun dan bioteknologi kelautan sebesar US\$ 4 miliar per tahun.
Potensi sumberdaya mineral dan energi

Sekitar $70 \%$ produksi minyak dan gas bumi Indonesia berasal dari kawasan pesisir dan laut. Dari 60 cekungan yang potensial mengandung migas, 40 cekungan terdapat di lepas pantai, 14 di kawasan pesisir, hanya 6 yang di daratan. Dari seluruh cekungan tersebut, potensinya diperkirakan sebesar 11,3 miliar barel minyak bumi. Cadangan gas bumi di kawasan ini diperkirakan sebesar 101,7 triliun kubik. Selain itu kawasan ini juga kaya akan berbagai jenis bahan tambang dan mineral seperti : emas, perak, timah, bijih besi, dan mineral berat. Di perairan pesisir dan laut Indonesia, juga ditemukan jenis energi baru pengganti BBM, berupa gas hidrat dan gas bionik di lepas pantai barat Sumatera, selatan Jawa Barat serta bagian utara Selat Makassar dengan potensi yang sangat besar, melebihi seluruh potensi minyak dan gas bumi Indonesia (Richardson, 2008 dalam Dahuri 2010).

Selain sumber energi diatas, terdapat juga sumber-sumber energi non konvensional seperti : energi pasang surut, energi gelombang, OTEC (ocean thermal energy conversion), tenaga surya dan angin. Potensi sumberdaya mineral lainnya yang dapat dikembangkan adalah air laut dalam (deep ocean water). Air laut dalam merupakan air di kedalaman $200 \mathrm{~m}$, memiliki karakteristik yang berguna untuk kepentingan perikanan, kosmetika dan air mineral.

\section{Potensi industri dan jasa maritim}

Sehubungan dengan Indonesia adalah negara kepulauan dengan wilayah pesisir dan lautan yang luas, maka industri dan jasa maritim yang potensi untuk dikembangkan adalah : a) Galangan (pembuatan) kapal dan dockyard; b) Industri mesin dan peralatan kapal; c) Industri alat penangkapan ikan (fishing gears) seperti jaring, pancing, fish finders, tali tambang, dll; d) Industri kincir air tambak (pedal wheel), pompa air, dll; e) Offshore engineering and structures; f) Coastal engineering and 
structures; g) Kabel bawah laut dan fiber optics; h) Remote sensing, GPS, GIS, dan ICT lainnya.

Potensi transportasi laut dan jasa lingkungan

Seiring dengan pergeseran pusat ekonomi dunia dari poros Atlantik ke Asia-Pasifik, dewasa ini, $70 \%$ perdagangan dunia berlangsung di kawasan Asia-Pasifik. Sekitar $75 \%$ produk dan komoditas perdagangan di transportasikan melalui laut Indonesia dengan nilai sekitar US\$1.300 triliun per tahun.

Sejak 1987, Indonesia menghamburkan devisa rata-rata US\$ 14 miliar/tahun untuk membayar armada pelayaran asing. Sekitar $97 \%$ dari total barang dan komoditas yang diekspor dan diimpor oleh Indonesia, diangkut oleh kapal-kapal asing dan sekitar 55\% dari total barang dan komoditas yang ditransportasikan antar pulau di perairan laut Indonesia, diangkut juga oleh kapal-kapal asing.

Dengan potensi total muatan nasional 502 juta ton per tahun (200 juta ton batubara; 55 juta ton crude oil; 60 juta ton CPO; 7 juta ton produk perikanan; 8 juta ton LNG; 2 juta ton LPG; 120 juta ton containers dan 50 juta ton general cargo), melalui pendekatan cluster maritime kita bisa meraup devisa perhubungan laut US\$ 15 miliar setiap tahun-nya (IMPC, 2008 dalam Dahuri 2009). Untuk dapat melayani kebutuhan angkutan muatan sebesar itu, diperlukan sekitar 650 kapal tambahan, dengan total investasi sebesar US\$ 5 miliar. Selain meningkatkan pendapatan negara, cluster maritime juga menciptakan lapangan kerja baru sedikitnya 1 juta orang, membangkitkan sejumlah multiplier effects, mendongkrak daya saing ekonomi nasional, juga dapat mempercepat pembentukan 24 pelabuhan hub port. Dari 114 pelabuhan umum yang kita miliki, tidak satupun memenuhi standar pelayanan internasional.

Tahun 2000, Jepang dengan panjang garis pantai $34.000 \mathrm{~km}$ memiliki 3000 pelabuhan perikanan, artinya setiap $11 \mathrm{~km}$ garis pantai terdapat 1 (satu) pelabuhan perikanan. Thailand dengan panjang garis pantai $2.600 \mathrm{~km}$ memiliki 52 pelabuhan perikanan, artinya setiap $50 \mathrm{~km}$ garis pantai mempunyai 1 (satu) buah pelabuhan perikanan. Sementara, Indonesia dengan panjang garis pantai kurang lebih $81.000 \mathrm{~km}$, hanya memiliki 17 pelabuhan perikanan, artinya setiap $4.500 \mathrm{~km}$ garis pantai hanya memiliki 1 (satu) buah pelabuhan perikanan.

Negara bagian Queensland, Australia dengan panjang garis pantai $2.100 \mathrm{~km}$, tahun 2007 pariwisata baharinya meraup devisa sebesar US\$ 3 milyar. Indonesia dengan panjang garis pantai $95.200 \mathrm{~km}$ dan 6 terumbu karang (Raja Ampat, Wakatobi, Tukang Besi, Bunaken, Gili IMT, dan P. Rubiah) dari 10 terumbu karang terindah di dunia, total devisa pariwisata nya hanya US\$ 5 milyar ( WTO 2008 dalam Dahuri 2010).

Posisi Indonesia yang strategis, dengan memiliki estetika lingkungan yang sulit ditandingi oleh negara kepulauan lain, seperti gugusan pulau yang indah dan kekayaan keanekaragaman sumberdayahayati lautnya, menjanjikan potensi ekonomi dari kegiatan pariwisata alam dan pariwisata bahari dengan segala variannya. Prospek ini tentu didukung oleh bergesernya kebutuhan masyarakat global akan kehidupan back to nature, dimana mereka telah jenuh dengan kehidupan dalam lingkungan buatan. Estimasi nilai potensi ekonomi pariwisata bahari di Indonesia sebesar US\$ 54.3 miliar per tahun (PKSPL IPB 2009 dalam Dahuri 2010)

\section{Potensi kultural}

Salah satu potensi kelautan Indonesia adalah benda peninggalan budaya masa lalu yang memiliki nilai ekonomis tinggi yaitu, Benda Muatan Kapal Tenggelam (BMKT). Saat ini diperkirakan terdapat 463 titik lokasi kapal tenggelam, yang terjadi sejak abad 14 sampai abad 19. Pemerintah telah membentuk Panitia Nasional 
BMKT melalui Keppres No.107 Tahun 2000, agar pemanfaatan BMKT dapat memberikan manfaat kepada masyarakat dan negara, serta mencegah pengangkatan BMKT secara illegal. Nilai BMKT secara keseluruhan diperkirakan mencapai US\$ 40 juta.

Dari potensi sumberdaya pesisir dan lautan di atas, sedikitnya terkait dengan 11 sektor ekonomi kelautan yang dapat dikembangkan yaitu : 1) perikanan tangkap, 2) perikanan budidaya, 3) industri pengolahan hasil perikanan, 4) industri bioteknologi kelautan, 5) pertambangan dan energi, 6) pariwisata bahari, 7) perhubungan laut, 8) industri dan jasa maritim, 9) sumberdaya pulau-pulau kecil, 10) coastal forestry (mangrove), dan 11) SDA non konvensional.

Sektor ekonomi kelautan adalah kegiatan ekonomi yang berlangsung di wilayah pesisir dan lautan, dan/atau yang menggunakan SDA dan jasa-jasa lingkungan kelautan untuk menghasilkan goods and services yang dibutuhkan umat manusia (Kildow, 2005 dalam Dahuri 2010). Menurut PKSPLIPB 2009, total potensi ekonomi kelautan Indonesia : sebesar US\$ 1.200 miliar/tahun

\section{Isu-isu pembangunan wilayah pesisir dan lautan Indonesia}

Potensi sumberdaya pesisir dan laut Indonesia yang besar ternyata belum memberikan kontribusi yang signifikan bagi pembangunan ekonomi nasional. Pemanfaatannya belum optimal, malahan telah terjadi degradasi sumberdaya alam di beberapa perairan pesisir akibat pemanfaatan yang tidak mempertimbangkan daya dukung lingkungan.

Adapun isu-isu utama dalam pengelolaan sumberdaya pesisir dan lautan di Indonesia antara lain :

\section{Kemiskinan masyarakat pesisir}

Wilayah pesisir merupakan wilayah dengan kepadatan penduduk yang tinggi, sayangnya sebagian besar masyarakat pesisir termasuk masya- rakat miskin. Tahun 2008, keberadaan masyarakat pesisir di Indonesia, tersebar di 10.639 desa pesisir, dimana masyarakat miskin-nya berjumlah kurang lebih 10 juta jiwa, terdiri dari 7,8 juta penduduk miskin dan 2,2 juta penduduk sangat miskin. Tahun 2011, masyarakat miskinnya bertambah menjadi 14,7 juta penduduk. Kemiskinan dan ketergantungan terhadap sumberdaya pesisir dan laut, seringkali mengakibatkan masyarakat melakukan kegiatan yang menurunkan kualitas sumberdaya, seperti : penebangan mangrove (untuk kayu bakar dan dijual), penangkapan ikan dengan merusak ekosistem.

\section{Konflik pemanfaatan ruang}

Berbagai kegiatan dan kepentingan dilaksanakan di wilayah pesisir, bahkan terkadang kegiatan-kegiatan tersebut saling bertentangan. Konflik pemanfaatan ruang terjadi, karena belum ada aturan yang jelas tentang penataan ruang wilayah pesisir yang dapat dijadikan acuan dari berbagai sektor yang berkepentingan.

\section{Penurunan kualitas lingkungan}

Kerusakan fisik pada ekosistem pesisir umumnya terjadi pada ekosistem mangrove, terumbu karang dan padang lamun. Terumbu karang dalam kondisi baik tidak lebih dari $30 \%$, sedangkan degradasi ekosistem mangrove hampir merata terjadi diseluruh kawasan pesisir Indonesia. Beberapa kegiatan yang diduga menyebabkan erosi pantai antara lain : pengambilan pasir untuk reklamasi, pembangunan pelabuhan/jetty/marina, pembangunan hotel. Hal ini terjadi karena perencanaan dan pengembangan wilayah pesisir yang tidak tepat.

Pencemaran yang terjadi di wilayah pesisir dan lautan, berasal dari aktivitas di darat seperti : industri, kegiatan rumah tangga dan pertanian. Selain itu ada juga sumber pencemaran yang berasal dari aktivitas di laut seperti : kegiatan transportasi laut, termasuk transportasi kapal pengangkut minyak (oil tanker), dan kegiatan 
pertambangan. Hal-hal inilah yang mengakibatkan terjadinya penurunan kualitas lingkungan perairan serta estetika pantai.

Pengelolaan pulau-pulau kecil dan pulau-pulau kecil di perbatasan

Mengingat karakteristiknya yang unik maka pengelolaan pulau-pulau kecil membutuhkan pendekatan tersendiri dan berbeda dengan pulau besar. Di masa lalu, perhatian untuk membangun pulau-pulau kecil sangat minim bahkan hampir tidak tersentuh oleh kegiatan pembangunan. Untuk itu dalam membangun pulau-pulau kecil disamping pengembangan untuk investasi, juga perlu diupayakan program pemberdayaan masyarakat yang ada di sana, seperti fasilitasi dan peningkatan sarana pendidikan, kesehatan, pengadaan listrik (tenaga surya), pengadaan alat desaltinasi, alternative livehood, bantuan sarana informasi dan telekomunikasi. Berdasarkan Perpres RI No.78 tahun 2005 tentang PengeIolaan Pulau-pulau Kecil Terluar, di daerah perbatasan NKRI terdapat 92 pulau-pulau kecil terluar yang perlu di kelola. Tujuan dari Perpres ini adalah untuk menjaga keutuhan NKRI, keamananan nasional, pertahanan negara, menciptakan stabilitas kawasan, pemanfaatan SDA secara berkelanjutan dan pemberdayaan masyarakat pulau-pulau kecil

Pengelolaan sumberdaya perikanan yang tidak berkelanjutan

Dari berbagai data yang dimiliki, kegiatan illegal fishing yang sering terjadi di perairan Indonesia, diantaranya : a) penangkapan tanpa izin, b) penangkapan dengan izin palsu, c) penangkapan yang tidak dilaporkan di pelabuhan pendaratan, d) penangkapan dengan alat tangkap terlarang, e) penangkapan di area yang tidak sesuai izin, dan f) penangkapan dengan jenis alat tangkap yang tidak sesuai izin.

Perubahan iklim global

Berdasarkan data Inter Govermental Panel on Climate Change
(IPCC), akibat pemanasan global, kenaikan suhu tahunan di Indonesia dari tahun 1970-2004 antara 0,2-10 ${ }^{\circ} \mathrm{C}$. Sedangkan dampak pemanasan global terhadap wilayah pesisir, adalah : a) wilayah pesisir semakin rentan terhadap erosi pantai maupun naiknya permukaan air laut, dan hal ini diperparah akibat perbuatan manusia, b) diperkirakan tahun 2080, jutaan orang akan terkena banjir setiap tahunnya, akibat naiknya permukaan laut, terutama dataran rendah yang padat penduduk terutama di delta-delta besar benua Asia dan penduduk di pulaupulau kecil, c) adaptasi untuk daerah pesisir lebih sulit dilakukan di negara berkembang karena terbatasnya kapasitas adaptasi mereka

Paradigma baru pembangunan
wilayah pesisir dan lautan di
Indonesia
Dalam skala nasional,
pengelolaan sumberdaya kelautan dan perikanan diharapkan dapat dikelola secara berkelanjutan serta mampu mensejahterakan masyarakat setempat. Di tingkat global, isu-isu perubahan iklim global (climate change), pengelolaan berbasis ecoregion (misalnya : coral triangle), dan konservasi lingkungan mendapat perhatian yang sangat penting. Tuntutan-tuntutan ini dianggap sebagai perhatian dan keprihatinan terhadap degradasi daya pulih lingkungan dan sumberdaya hayati. Tuntutan ini tertuang dalam berbagai konvensi internasional menyangkut pengelolaan wilayah pesisir terpadu, pengentasan kemiskinan, dan pengelolaan perikanan yang bertanggung jawab, seperti Agenda-21, World Summit on Sustainable Development (WSSD), Millenium Development Goals (MDGs) dan Code of Conduct for Responsible Fisheries (CCRF).

Dengan telah mengantisipasi beberapa kondisi lingkungan strategis sesuai dinamika perkembangan di tingkat global dan nasional, maka pengelolaan sumberdaya kelautan dan perikanan Indonesia ke depan, 
diharapkan dilakukan secara terpadu sesuai dengan daya dukung lingkungan serta untuk memberdayakan masyarakat pesisir dan pulau-pulau kecil.

Kebijakan pembangunan kelautan dan perikanan

Dalam upaya pengelolaan potensi sumberdaya kelautan dan perikanan, selain memberikan penyadaran tentang pentingnya manfaat dari sumberdaya kelautan dan perikanan untuk meningkatkan kesejahteraan masyarakat, juga perlu ditanamkan tentang falsafah dalam mengelola sumberdaya tersebut, harus dengan pendekatan ekonomi, ekologi dan sosial, sehingga tercapai keseimbangan antara eksploitasi dan konservasi.

Kementerian Kelautan dan Perikanan $\mathrm{RI}$, telah menyusun rencana strategis pembangunan sektor kelautan dan perikanan dengan visi : "Pengelolaan sumberdaya kelautan dan perikanan yang lestari dan bertanggung jawab bagi kesatuan serta kesejahteraan anak bangsa". Sedangkan misi kementerian ini adalah :

- meningkatkan kesejahteraan masyarakat nelayan, pembudidaya ikan dan masyarakat pesisir lainnya; meningkatkan peran sektor kelautan dan perikanan sebagai sumber pertumbuhan ekonomi

- Memelihara daya dukung dan meningkatkan kualitas lingkungan perairan tawar, pesisir, pulau-pulau kecil dan lautan (sumberdaya kelautan dan perikanan)

- Meningkatkan kecerdasan dan kesehatan bangsa melalui peningkatan konsumsi ikan

Meningkatkan peran laut sebagai pemersatu bangsa dan memperkuat budaya bahari

Untuk mewujudkan visi dan misi ini, maka pembangunan bidang kelautan dan perikanan bertumpu pada tiga pilar pembangunan nasional yaitu : pro growth strategy; pro job strategy dan pro poor strategy, yang diarahkan pada:
- Penanggulangan kemiskinan dan kesenjangan antar daerah

- Peningkatan kesempatan kerja, investasi dan ekspor

- Penegakan hukum dan penanggulangan illegal fishing

- Peningkatan aksesibilitas dan kualitas pendidikan/kesehatan bagi masyarakat pesisir

- Rehabilitasi daerah-daerah yang terkena bencana alam (mis : Aceh, Nias, dll)

Penguatan kelembagaan (UU pengelolaan pesisir dan pulau-pulau kecil)

Implementasi berbagai kebijakan dalam mengelola wilayah pesisir dan pulau-pulau kecil selama ini mengalami kendala karena tidak adanya payung hukum, untuk dijadikan landasan kebijakannya. Untuk menjawab permasalahan ini, lahirlah UU No.27 Tahun 2007 tentang pengelolaan wilayah pesisir dan pulau-pulau kecil. UU ini mempunyai arti penting dan strategis bagi pembangunan wilayah pesisir dan pulau-pulau kecil di Indonesia. Dan juga menjadi momentum penting dan strategis sebagai pengakuan negara akan pentingnya pengelolaan wilayah pesisir dan pulau-pulau kecil. Adapun implikasi dari lahirnya UU. No.27 Tahun 2007 ini adalah :

- Perubahan paradigma pembangunan dari berbasis sumberdaya daratan ke sumberdaya kelautan

- Perubahan kebijakan pengalokasian anggaran pembangunan dengan memperhatikan parameter luas wilayah perairan laut

- Perubahan pendekatan pembangunan sesuai dengan karakteristik bio-geofisik wilayah P3K

- Obligasi bagi pemerintah, dunia usaha dan masyarakat untuk memitigasi bencana di wilayah P3K

- Membuat sepadan pantai, dan mengkonversi wilayah pesisir untuk : perlindungan wilayah pesisir, pelestarian biodiversity, perlindungan manusia dari bencana, pelestarian nilainilai sosial budaya pesisir 


\section{- Ada kebutuhan capacity building di bidang pengelolaan wilayah pesisir terpadu (integrated coastal mana- gement)}

Mitigasi dan adaptasi wilayah pesisir dan pulau-pulau kecil

Wilayah pesisir dan pulau-pulau kecil merupakan wilayah yang paling rentan terhadap dampak perubahan iklim, seperti terjadinya kenaikan paras muka laut (sea level rise) yang akan menenggelamkan pulau-pulau kecil yang berelevasi rendah. Hilangnya pulau-pulau kecil di wilayah perbatasan $\mathrm{NKRI}$, dapat mengancam kedaulatan wilayah NKRI. Selain itu, perubahan suhu dan sifat fisik kimia air laut akan berdampak negatif terhadap biodiversity dan pola migrasi spesiesspesies penting.

Untuk itu, upaya mitigasi dan adaptasi terhadap perubahan iklim global telah menjadi suatu keharusan. Perencanaan pembangunan di wilayah P3K harus mempertimbangkan aspek resiko dan mitigasi bencana yang mungkin dihadapi baik dalam jangka pendek maupun jangka panjang. Selain itu, upaya-upaya peningkatan daya tahan (resilient) masyarakat pesisir terhadap perubahan iklim global tersebut juga perlu terus dilakukan.

\section{Pemberdayaan masyarakat pesisir}

Masyarakat pesisir adalah orang yang tinggal di daerah pesisir dan sumber kehidupan ekonominya bergantung secara langsung pada pemanfaatan sumberdaya laut dan pesisir. Mereka terdiri dari : nelayan pemilik, buruh nelayan, pembudidaya ikan/ organisme laut lainnya, pedagang ikan, pengolah ikan, supplier faktor sarana produksi perikanan. Di bidang non perikanan, terdiri dari : penjual jasa pariwisata bahari/pesisir, penjual jasa transportasi laut, kelompok masyarakat yang memanfaatkan sumberdaya nonhayati laut dan pesisir untuk kehidupannya.

Sebagian besar penduduk yang tinggal di wilayah pesisir merupakan masyarakat miskin. Kondisi ini dise- babkan keterbatasan kemampuan dan pengetahuan, terbatasnya akses terhadap permodalan, teknologi, informasi dan pasar, serta keterbatasan masyarakat dalam keterlibatan untuk pengambilan keputusan alokasi sumberdaya pesisir dan pulau-pulau kecil. Kondisi ini kalau dibiarkan, berpotensi untuk meningkatkan eksploitasi sumberdaya kelautan dan perikanan yang tidak ramah lingkungan. Untuk itulah dibutuhkan program pemberdayaan bagi masyarakat pesisir, dengan tujuan sebagai berikut :

- Tersedia dan terpenuhinya kebutuhan dasar manusia yaitu : sandang, pangan, papan, kesehatan dan pendidikan

- Tersedia sarana dan prasarana produksi secara lokal, sehingga masyarakat dapat memperolehnya dengan harga yang murah dan berkualitas

Meningkatnya peran kelembagaan masyarakat sebagai wadah aksi kolektif

Terciptanya kegiatan ekonomi produktif di daerah yang berbasis sumberdaya lokal (resources based) dan dilakukan secara berkelanjutan dengan memperhatikan kapasitas sumberdaya (environmental based).

Kerjasama regional dan internasional Mengingat perubahan iklim merupakan permasalahan global dan dampaknya bersifat lintas batas negara, maka kerjasama antar negara perlu dikembangkan. Khusus untuk wilayah pesisir, hal ini sangat penting mengingat pengelolaan sumberdaya pesisir bersifat bio-ekoregion, daripada administratif.

Beberapa kerjasama regional maupun internasional yang berhubungan dengan hal di atas antara lain :

\section{World Ocean Conference (WOC) 2009}

Adalah konferensi kelautan dunia, yang dilaksanakan di kota Manado, Sulawesi Utara, Mei 2009. Secara umum konferensi ini bertujuan untuk mendapatkan komitmen politik dari 
pemerintah negara-negara yang hadir, dan secara khusus bertujuan untuk meningkatkan pemahaman tentang : (a) perubahan iklim dan pengaruhnya terhadap kesejahteraan sosial dan ekonomi masyarakat pesisir, kondisi lingkungan laut serta wilayah pesisir, (b) peran laut dalam fenomena perubahan iklim global, (c) langkahlangkah adaptasi dan mitigasi untuk menghadapi perubahan iklim global.

Hasil dari WOC 2009 ini adalah dideklarasikan Manado Ocean Declaration, yang berisi : (i) Dampak perubahan iklim terhadap laut; (ii) Peran laut dalam mengelola iklim global; (iii) Adaptasi dan mitigasi; (iv) Peluang kerjasama regional dan internasional.

\section{CTI (Coral Triangle Initiative)}

Coral Triangle Initiative (CTI) on

Coral Reefs, Fisheries and Food Securities, merupakan forum koordinasi dalam pengelolaan perikanan yang penting dan modern, mencakup sebagian wilayah zone ekonomi eksklusif 6 (enam) negara yaitu : Indonesia (bagian tengah dan timur), Timor Leste, Filipina, Malaysia (Sabah), Papua New Guinea, dan kepulauan Solomon. Inisiatif ini sekaligus menggalang upaya penguatan human system dalam pengelolaan terumbu karang dan natural system dalam menjaga kelestarian ekosistem terumbu karang dan mengantisipasi perubahan iklim global.

Kerjasama CTI merupakan pendekatan baru dalam pengelolaan sumberdaya yang berbasis bioekoregion. Pendekatan pengelolaan ini dilakukan secara bersama pada kawasan penting dan signifikan dalam satu kesatuan dan keterkaitan ekosistem (bio-ekoregion) dalam batas-batas tertentu, dan tidak terlalu kaku dalam batas-batas wilayah administrasi negara.

Kawasan CTI, meliputi luasan sebesar $75.000 \mathrm{~km}^{2}$, memiliki 500 spesies terumbu karang, 3000 spesies ikan, sebaran hutan bakau tersebar di dunia, sebagai tempat pemijahan dan pengembang-biakan ikan tuna, yang menyediakan bahan baku bagi industri perikanan tuna dunia. Kawasan ini juga merupakan sumber penghidupan bagi 120 juta penduduk, dengan perputaran ekonomi sebesar \$2,3 milyar per tahun.

\section{KESIMPULAN}

Secara geografis Indonesia terdiri dari pulau-pulau besar dan kecil yang jumlahnya kurang lebih 17.504 pulau. Tiga perempat wilayahnya adalah laut (5,9 juta km2), dengan panjang garis pantai $95.161 \mathrm{~km}$, terpanjang kedua di dunia setelah Kanada. Hal ini menjadikan Indonesia sebagai negara kepulauan terbesar di dunia (the biggest Archipelago in the World). Namun faktanya, pembangunan bidang kelautan dan perikanan selama ini masih jauh dari harapan.

Pengelolaan sumberdaya kelautan dan perikanan membutuhkan kebijakan yang komprehensif, terintegrasi dan tepat sasaran, mengingat kawasan ini memiliki permasalahan, potensi dan karakteristik yang khas. Dengan lahirnya UU No.27 Tahun 2007, telah memberikan makna strategis sekaligus tantangan bagi implementasi pengelolaan sumberdaya kelautan dan perikanan di Indonesia.

Hal yang paling penting untuk menjadikan kelautan dan perikanan sebagai sektor andalan pembangunan adalah perlunya perubahan paradigma pembangunan. Dimana pendekatan pembangunan selama ini yang lebih berorientasi darat, harus dirobah menjadi berorientasi ke-laut, dengan lebih memperhatikan dan mengoptimalkan sumberdaya wilayah pesisir dan lautan.

Selain itu, dengan adanya desentralisasi dalam pengelolaan sumberdaya pesisir dan laut ke daerah (kabupaten/kota dan provinsi), maka upaya peningkatan kualitas SDM di daerah perlu dilakukan sebagai ujung tombak pelaksana kebijakan kelautan dan perikanan nasional. Dengan adanya capacity building dan kemitraan 
dengan berbagai pihak maka implementasi konsep pengelolaan wilayah laut, pesisir dan pulau-pulau kecil yang terpadu akan terlaksana dengan baik.

\section{DAFTAR PUSTAKA}

Dahuri R. 2010. Positioning Perguruan Tinggi dalam Pembangunan Kelautan Nasional. Bahan Kuliah Umum di Fakultas Perikanan dan IImu Kelautan UNSRAT Manado. 206 p

Dahuri R, J. Rais, S. P. Ginting, M. J. Sitepu. 1996. Pengelolaan Sumberdaya Pesisir dan Lautan Secara Terpadu. PT. Pradnya Paratima. Jakarta

Direktorat Jenderal Kelautan, Pesisir dan Pulau-pulau kecil-DKP. 2001. Naskah Akademik Pengelolaan Wilayah Pesisir. Departemen Kelautan dan Perikanan Rl. Jakarta
Kusumastanto T. Makalah. Ocean Policy dalam Membangun Negara Bahari. PKSPL IPB

Numberi F. 2009. Evolusi Pembangunan Kelautan dan Perikanan Indonesia. Makalah disampaikan pada Seminar Nasional Evolusi Kelautan Nusantara. Bogor. $32 \mathrm{p}$

Peraturan Presiden RI No.78 Tahun 2005 tentang Pengelolaan PulauPulau Kecil Terluar.

Sujoko A. 2011. Akankah nelayan bebas dari kemiskinan. http:// opiniperikanan.wordpress.com. di akses tanggal 3 Juni 2012.

United Nations, United Nations Convention on The Law of The Sea, 10. December 1982.

Undang-Undang RI No.17 Tahun 1985 tentang Pengesahan United Nations Convention on The Law of The Sea.

Undang-Undang RI No.27 Tahun 2007 tentang Pengelolaan Wilayah Pesisir dan Pulau-Pulau Kecil 